\title{
'A Bit of a Grope': Gender, Sex and Racial Boundaries in Transitional East Timor
}

\author{
Roslyn Appleby, University of Technology, Sydney
}

\section{Introduction}

The promotion of gender equality has, in recent decades, been a central concern in international development projects, and is enshrined in international agreements and commitments including the Millennium Development Goals. Yet the enactment of these goals in the intercultural contact zone of development has been problematic, as development workers struggle to balance sometimes-contradictory discourses of gender equality and tolerance for cultural difference. For white women working in development, this struggle can be particularly difficult. On the one hand, women may be marginalised within the patriarchal culture of international development and, at the same time, find themselves the target of local men's hostility and aggression. While research and plans to promote gender equality in a global arena have, appropriately, primarily focused on the opportunities and barriers faced by women in 'recipient' communities, few empirical accounts have tackled the ambiguities inherent in the positioning of white women as international aid workers.

This article takes up these concerns by focusing on the gender positioning of white Australian women who were employed as foreign aid workers in East Timor during the military and aid intervention of 2000-2002, following the country's historic vote for independence from Indonesia. Drawing on the narrative accounts of seven of the women I interviewed as part of a larger study, ${ }^{1}$ the article explores the challenges the women faced in negotiating gender relations with men in the international aid

\footnotetext{
${ }^{1}$ The interviews represent part of a larger study published in Appleby (2010). 
community and in the Timorese community. My interpretation of their accounts, shaped in part by my own experiences of teaching English in East Timor during the same period of international occupation, demonstrates the women's complex and contradictory positioning as both international aid workers and cultural aliens.

The following two sections are intended to situate the women's experiences as actors within a broader geopolitical domain of international intervention and occupation. The first locates the women's aid work within the historical context of intervention in East Timor; the second provides a critical account of the intervention's intended aims of gender reform. I then turn to my discussion of the women's accounts. In that discussion, I focus in particular on the women's narration of encounters in public space as a contested domain in regard to the spatial regulation of gender and race (Rose 1993), and in a contact zone 'where cultures meet, clash, and grapple with each other, often in highly asymmetrical relations of domination and subordination' (Pratt 1992: 4).

\section{Intervention, occupation, and the transition to independence in East Timor}

The 2000-2002 international aid effort in East Timor can be understood as one phase in a long history of intervention and occupation, marked by over four centuries of Portuguese colonialism and 24 years of Indonesian occupation and incorporation into the Indonesian state. Indonesian occupation came to an end in 1999 when the people of East Timor voted overwhelmingly for independence. Violence escalated following the announcement of the results, with massacres and large-scale destruction of properties and infrastructure as Indonesian troops and supporters withdrew. By September, civil society was in a state of collapse with the cessation and withdrawal of all civil, government, legal and administrative functions, and the destruction of seventy percent of the physical infrastructure and 90 percent of housing (Chopra 2002).

In order to quell the violence, Indonesia approved the intervention of an Australian-led multinational peacekeeping force whose strength ultimately reached 11,500 troops (Chopra 2000: 28). The International Force East Timor (INTERFET) was charged with restoring security, and in 2000 formally handed over military command to a UN peacekeeping operation and the United Nations Transitional Administration for East Timor (UNTAET). This set the tone for a co-location of the aid effort with a masculinised military presence. Supported by a military strength of 8,950 troops, 200 military observers, and a civilian police force of 1,640, UNTAET assumed its mandate 
to maintain law and order, rebuild the structure of government and public administration, develop civil and social services and coordinate humanitarian assistance during East Timor's transition to full independence in 2002. Alongside the UN mission, a vast array of government and non-government organisations arrived and took a major role in the reconstruction of East Timor through the mobilisation of emergency relief efforts and the channelling of aid funds and expertise into a huge range of assistance programs in housing, health, education, welfare, public administration, business and industry.

English language education programs were a key element in the educational assistance provided by Australia. All the women in this study were professional English language teachers, much in demand in the early emergency phase of national reconstruction due to the sudden withdrawal of Indonesian teachers from East Timor, and because of the use of English as the lingua franca of the foreign intervention.

\section{Gender reform and international intervention}

The women aid workers' negotiation of everyday gender interactions can be considered in light of the stated goals for gender reform that were a feature of the transitional period. UNTAET's peacekeeping and development operations were to include a focus on 'gender mainstreaming,' in keeping with contemporary development thinking that gender perspectives should be considered in the design and delivery of every aid project. The inclusion of a gender perspective in aid projects is primarily understood in terms of gender inequality as a problem located within the recipient community, a problem manifest, for example, in poor participation rates for girls in formal education. In this way, developed and developing communities are conceived in a dichotomous relationship: the developed world is constituted as a place of modern attitudes and approaches towards gender equality, in contrast with the developing world which is constructed as a place of traditional, patriarchal notions of gender oppression. In this regard, it is useful to recall Spivak's argument that one 'justification of imperialism as a civilising mission,' as opposed to a mission for the expansion of Western capitalism, was to be found in the actions of "white men, seeking to save brown women from brown men' (1994: 10). While the opportunities and freedoms available to women and girls in developing countries may indeed be limited, focusing solely on problems in the recipient community serves to mask persistent inequalities in the developed world, assumes that Western women are liberated and in control of their own lives, and fails to 
adequately address the conflicts that arise when, and because, development enterprises occupy sites in the developing world.

Development projects may require that aid workers strive to combat the social and moral injustices of sexism, racism, class exclusion and so on, but the various interests of social justice are sometimes in conflict, as can be seen in the debates between First World and Third World feminism on the issue of feminist cultural imperialism. Within feminist circles, there has been much debate over the way gender interests are conceived, represented and investigated. Critiques of a 'superior "we know best" attitude of Western feminisms' have complicated approaches to gender (Pearson \& Jackson 1998: 7) and implicated white women in the paternalistic, neocolonial discourses of development (Wells \& McEwan 2004). On the other hand, the retreat to 'culture and tradition' as a means of resisting neocolonial interference has, in some circumstances, prevented women from 'overcoming discrimination and enjoying basic human rights' (Hunt 2004: 258). While attempts to relocate gender politics often focus on a global 'human rights' framework, feminist poststructuralists have also emphasised the importance of engagement with women's local, everyday struggles, and 'rhizomatic practices' of resistance, to develop an 'emancipatory politics' (Yeoh, Teo \& Huang 2002: 3). The latter attempt to avoid essentialist notions of, and transhistorical claims about, gender in favour of situated, contextualised analyses that consider the intersection of gender/power relations with other axes of difference in the politics of change (Hawthorne 2004). Nevertheless, as I attempt to demonstrate in this study, these ideals leave the position of white women aid workers in a dilemma about how to negotiate competing desires for gender equality and cultural sensitivity in their own everyday interactions and encounters.

In transitional East Timor, these debates and dilemmas were particularly acute. Claims that East Timor is a patriarchal society, one in which women have suffered disproportionately under waves of occupation, are found amongst both Timorese and Western scholars, with some alleging that customary tribal practices, Portuguese colonialism and Catholicism have contributed to women's oppression (see, for example, Charlesworth \& Wood 2002; de Araujo 2007; Joshi 2007). However, in the transitional period between 1999 and 2002, despite the establishment of a Gender Affairs Unit in UNTAET, observers have claimed that achievements in improving gender equality were 
limited not only by patriarchal traditions, but also by poor planning, limited funding, hostility from male officials within the UN mission, and the masculine nature of the UN enterprise itself (Charlesworth 2008). Indeed, 97.6 percent of the peacekeeping forces and 96 percent of the international civilian police were male; and although 33 percent of the civilians in UNTAET were women, almost all the key positions were held by men (Charlesworth 2008). Amongst aid agencies, women were represented in the traditional areas of health and education, yet leaders and administrators in those programs also tended to be male. In these circumstances, Joshi (2007) has argued that a militarised and masculinised UNTAET, under the control of a male dominated Department of Peace Keeping Operations, exacerbated gender problems in East Timor and failed to protect civilian women from sexual violence perpetrated by international military and police personnel.

From the perspective of critical development studies, the problematic gender relations within the aid program were symptomatic of a pattern in which aid is closely associated with a masculinist culture of military intervention. In such interventions, a democratic project for introducing gender equality in parts of the world where women are oppressed may be used to legitimate a conservative militarist agendas (Eisenstein 2007); yet the masculinised nature of military operations may serve to aggravate iniquitous gender effects in conflict and post-conflict zones (Mazurana, Raven-Roberts, Parpart \& Lautze 2005). This raises significant dilemmas for the pursuit of gender equality through aid programs, and may ultimately exacerbate conditions of inequality for women on both sides of the development divide.

In the following sections, I discuss the complex and contradictory positioning of white women working on development projects in East Timor, and contrast their experiential accounts in relation to men in the international community and the Timorese community. On the one hand, the women's responses to men in the international community display an explicit rejection of the subservient subject positions offered by a masculinist development culture. By contrast, in their encounters with Timorese men, the women's self-positioning was more ambivalent, as they attempted to juggle competing discourses of gender equality and cultural sensitivity, and to accommodate an awareness of their own intrusion and occupation of Timor as a place that was not their own. The women's contrasting responses point to the ambiguous position of white women as alien 
occupiers, and highlight the dilemmas they face in finding an appropriately gendered role in the development enterprise as an intercultural domain.

\section{Gender relations within the international community}

Working in Dili, the location of the greatest number of foreign workers, the women in this study experienced the public social space of the intervention and development enterprise to be intensely patriarchal, and assessed much of the behaviour of foreign men as 'incredibly sexist.' Accounts of the perceived sexism that prevailed within the privileged foreign development community, suggest that while the women teachers in this study enjoyed mixed social interaction on their own terms, they vigorously opposed the scrutiny of an objectifying male gaze (Appleby 2009, 2010). They bristled at perceived gender hierarchies in an overarching patriarchal development regime, and resisted involvement in social practices that they experienced as hostile to women.

For these women, the social spaces produced by the development community appeared to enable an exaggerated, muscular masculinity: from their perspective, this was a 'blokes' world.' In the opinion of one teacher, Elly, ${ }^{2}$ the emergency scenario and war games, the expectation and evidence of violence and conflict, appeared to attract men who "would just never get jobs with that sort of authority or money or sense of importance at home, and they can do it all in these situations.' This vision of a conflict zone in which men dressed in 'little military outfits' were barking orders and exercising control over people and situations, echoed with the legacies of an earlier colonial era where the empire was envisaged as 'a place of masculine endeavour, where heroic individual males behave in adventurous ways, exploring undiscovered lands and subduing the inhabitants' (Mills 1994: 36-37).

The privileging of hegemonic masculinity tended to marginalise female teachers who felt excluded by the muscular pursuits of a militarised development mission. In Elly's view, the gendered construction of public space in East Timor meant that women aid workers were 'a bit of an anomaly.' She added: 'The whole set-up was still kind of quite patriarchal because it was still so war-oriented ... there was something very "wargames-y" about the whole scene, and male about it.' This male scene appeared to contain an implicit message to women: 'Watch out, it's males that operate here!'

\footnotetext{
${ }^{2}$ All participants are referred to by pseudonym.
} 
I didn't feel like "watch out because women are being attacked on the streets" ... it was more kind of "this is very much a war zone and you don't know very much about that whole kind of thing so just be careful." That's what I felt. Like we were not really meant to be there, as a gender. Like as aid workers, yes, but as women aid workers, there was something a bit funny.

While the women saw themselves as having a legitimate professional role as educators, they believed they were seen by men as lightweight, uncommitted and middle class. Another teacher, Helen, suspected 'professional jealousy' was at the heart of the criticisms and exclusions directed at teachers, who were 'easy targets, because people seem to imagine that we have a light job.' Such 'light jobs' could be contrasted to the masculinised, physical work undertaken in development sites, such as Timor, characterised by danger and designated for emergency relief. In related recollections, Fay suggested that in the eyes of male aid workers, 'we were this sort of bunch of middle-class teachers from Australia with no commitment,' cast as outsiders in a masculinist hierarchy.

Without legitimacy in a masculine domain, Elly felt the teachers were viewed as 'sex objects,' and as 'meat market' prey in a social scene comprising 'the whole nightclub scene' and hotels where 'predatory Australian men' would congregate to 'scoff at the trough, drink beer, and watch violent, noisy videos.' These were viewed as hostile places where women were subject to close inspection, groping and harassment. Elly reasoned that by travelling overseas, normal social expectations had been removed, allowing some men to enter a time warp and 'revert to that type of behaviour' whereby women's bodies are constituted and controlled through the scrutiny of the male gaze.

In sum, these women's accounts constituted the development community as a patriarchal domain in which foreign men occupied a position of dominance, and in which women were out of place. Moreover, men's behaviour in the NGO and UN circle was perceived as doubly inappropriate: the gendered performances were not only anachronistic and historically dislocated, reflecting outdated norms that would be unacceptable at home, but also geographically inappropriate in being transposed into another cultural space where different norms and sensitivities may need to be considered.

The dominant position of a militarised, masculinised foreign community was consolidated by notions of Timor as a dangerous place. During the transitional period, 
rumours of political instability and impending militia attacks justified the continuing foreign occupation as a means of controlling the threat of Timorese violence. Foreign workers were warned to exercise caution, not to venture out alone or at night, not to go to the beach, and to stay away from any meetings or gatherings of people. The effect of these warnings was to secure a patronising, protective role for men who, in Helen's experience, were 'hectoring us about how to keep safe. They all do it.'

From the teachers' perspective, the potential dangers were construed as a threat to expatriate women's safety, and added to their sense of being monitored and controlled. With white women implicitly 'mythologized as the desired objects of colonized men' (Stoler 1995: 183), a discourse of fear was mobilised by masculinist claims to know what the dangers were and how to avoid them (Rose 1993). Those claims for territorial control necessitated the redrawing of racial boundaries, and reaffirmed the need to monitor and confine women within secure physical spaces. In the complex patterns of gendered behaviour in this space, we can see Stoler's point that 'sexual desire in colonial and postcolonial contexts has been a crucial transfer point of power, tangled with racial exclusions in complicated ways' (Stoler 1995: 190).

\section{Gender relations between white women and Timorese men}

While most of the women in this study did recount incidents of unwanted attention or harassment by Timorese men, their responses to these threats were complex and varied. Despite hostile incidents of being watched, followed or confronted by Timorese men, often in isolated public spaces, they positioned their own responses within discourses of cultural sensitivity, rather than asserting their rights to gender equality. As outsiders, the women could only make assumptions about Timorese sexual mores and how Western women were identified by Timorese men. Acting on their assumptions, the women tended to adopt strategies that, first, served to diminish or excuse threatening behaviour from Timorese men, and second, aimed to defuse the effects of this behaviour by modifying their own bodily performance in an effort to avoid antagonising perceived Timorese gender norms. In adopting these strategies, the women's contrasting reaction to Western men and Timorese men is of interest: whereas the attempted regulation by Western men was repudiated by the women as doubly inappropriate, the women's reflexive, ambivalent response to Timorese men suggested a greater inclination to see Western women, including themselves, as being inappropriate in that space. 


\section{Dismissing: just a bit of a grope}

An apt example of the difference between women's responses to Western and Timorese men is demonstrated in the contrasting accounts of physical touching recalled by Helen and Fay. Helen complained bitterly of the unwanted attention she had received from Western men, and in particular she criticised the way in which one Western man had pursued, harassed and touched her inappropriately. She found this particularly irksome when this happened in the presence of Timorese company. Helen's concerns point to underlying assumptions about conservatism on matters of gender and sexuality in Timorese society:

I just had real hassles with this [Australian] contract engineer who really harassed me, who really gave me the shits actually. You know, touching me in the wrong way, and bothering me, winding me up in front of Timorese or, you know, grabbing me in the wrong- you know, if anything like that happens in front of the Timorese it's ten times worse, he did it to me at a party and I just nearly died. Awful.

By contrast, Fay's experience of a series of unwanted sexual approaches by Timorese men was dismissed as a minor irritation because 'I didn't feel there was a threat of violence, no I didn't feel that it was going to go over into anything more than perhaps a bit of a grope.'

\section{Diminishing: just a little bit frightened}

A similar strategy adopted by the women was to diminish the threat of harassment by understatement. In the following account, I turn to the beach as a site that was particularly challenging in terms of gendered and sexualised intercultural encounters. The beach had become something of haven for teachers who wanted to escape stifling classrooms or cramped houses shared with other development workers. Escaping for a walk along the beach at the end of a long teaching day carried out in extreme heat, the women were routinely followed by Timorese men calling out verbal greetings, ranging from the benign 'Hello Missus,' to stronger suggestions such as 'You fuck I!'

Although Elly described the experience of walking in this contested public space as 'horrific,' others, like Dana, tended to understate the effect of being targeted as 'the centre of attention' by the male gaze.

People looking at you because you're a woman, on the beach, you know what it's like, appearing in your bathers not with-you know with the East Timorese (laughs) um, yeah just getting hassled. I remember there were incidents where people followed me and Elly, where I got-where I had somebody waiting on the beach for me if I went in for a swim. That kind of thing, it was a bit 
intimidating. On the street, you know I'd be riding my bike around but um, you know I felt okay because I was on my bike, but um, but yeah I didn't feel as safe as I would have riding around the streets of Sydney. (...) I was just a little bit frightened sometimes, not all the times, but, just a little bit frightened. I don't think it ever-maybe that I would get attacked or that my bike would get stopped or maybe I'd get robbed. Not that much, you know I've been more intimidated in other countries, as a woman.

Dana's account demonstrates a cautious, or tentative response to Timorese harassment, as the otherwise intimidating effects are diminished by constant moderation ('a little bit frightened'), and by positive comparison with other locations (Sydney and 'other countries').

\section{Rationalising: it can happen anywhere}

Even in instances of physical assault, the threat posed by Timorese men was diminished through related strategies of rationalisation, as can be seen in Anne's account of harassment by a Timorese man. When walking around the streets of Dili, Anne had initially 'never felt any threat to my security,' and felt protected by an identity she projected as a valued professional aid worker and English teacher, and also as someone who fitted in with the local community:

I didn't mind walking anywhere, and I didn't mind walking in the pitch dark where there were no lights, and [I thought] 'all the people round here know me' and I felt there was safety in that. Walking through the markets every day, even though people would say, 'oh the market place is dangerous,' but all the shopkeepers knew me and called out to me and I always thought, 'if there's ever any trouble, I think they'd help me, I really do.'

However, this sense of regard and protection was disrupted when, walking home alone one night, she was followed and grabbed by a man: 'I guess I was shocked, and my reaction was to yell at him, and I yelled at him in Indonesian, and I said: "I live here, I have lots of friends here, if I yell right now you are in big danger. Get out of here! Go!"” The man fled, but the incident changed her sense of herself in public:

What I found after that, I was so furious because I thought: 'you've just spoilt it for me, up till now I didn't mind walking anywhere' (...) But after that, I thought: 'I can't go out on my own any more. Suddenly I was really conscious of that, especially at night time, but I was more wary all the time. I was so angry that I should have to be. And I did think later: 'come on, you know, that can happen anywhere in the world, not just in Timor.'

This incident made Ann reconsider her position in the social order. Whereas she had assumed a position of power, in part secured through her identity as a white professional, she had now been reminded of her vulnerable status as an isolated female out alone at night. However, anger over the individual attack, and its implications for her sense of 
worth and freedom, her sense of belonging, was eventually rationalised, naturalised, and transformed into a recognition of what she saw as women's universal experience: a restriction on mobility enforced by the threat of violence.

\section{Excusing: emasculation by foreign intervention}

Timorese men's behaviour was also excused by considering their position in relation to the Western invasion of development aid workers. From the women's viewpoint, the intervention of busy foreign aid workers had exacerbated racial and economic inequalities that disadvantaged Timorese men. While the large and highly paid international workforce was fully employed reconstructing the country, local unemployment remained high. The few jobs that were available to Timorese, working as 'drivers, security guards and interpreters in an administration dominated by foreign experts' (Sword-Gusmao 2003: 302), were paid at a daily rate of \$5, while the United Nations paid 'New York salaries for its own staff' (O'Kane 2001: 21). As one of the women teachers observed, while the streets had become the public domain of a privileged, masculine, 'UN junket,' groups of 'bored and frustrated young men feeling like second class citizens,' were robbed of their agency in the face of an intervention by wealthy outsiders.

\footnotetext{
There were a lot of foreigners going running and stuff like that, with their wallets and what have you, early in the morning or at dusk, and making themselves vulnerable really, just not understanding that there would be that rather odd reaction to them. But there was also a lot of hostility on the street, the brutalised atmosphere and a lot of frustrated young people around. There's no money and that massive UN gravy train where people- the place was really, really full of foreigners living very affluent lifestyles, driving around and throwing money about, so I think at that point, those contradictions were really intense.
}

Several of the women, including Dana, recognised that the teachers were complicit in this contradictory activity, 'being over there and having money and having jobs and (...) another occupier coming in, an unofficial one,' and that female teachers were therefore a target of resentment by disenfranchised masculine Timorese hostility. Dana wondered whether the anger provoked by Western affluence and agency was perhaps more easily expressed as an exercise of power over Western women rather than Western men: 'if you're not feeling very powerful, then sexually harassing someone can make you feel pretty powerful, if that person is seen as pretty frightened and pretty vulnerable.'

\section{Blaming: Western women's sexuality}

The teachers also suspected that certain beliefs about Western women's sexuality may 
have affected their interactions with Timorese men. In Fay's opinion, there was 'obviously that fascination with Western sexual mores and there was quite a lot of fascination there with that, with Western women who have sex and um, disapproval of it at the same time, a sort of antagonism.' It was, perhaps, this fascination or intrigue that was evident in one perplexing incident recounted by Fay. When travelling with a white male companion, they had been approached by 'a Timorese man who came up to [my male companion] and took him away and started talking about 'fucky fucky' or something like that, it was in those sort of terms and um, I don't know what he actually wanted, um, it was about me [but] I don't know what was happening there.'

Incidents that occurred when walking on the beach with female companions were represented as similarly confusing: 'Those episodes on the beach and the whole thing about Western women and sex and- oh dear! I didn't know where all that came from there, whether it was having some Westerners behave like Westerners, be publicly affectionate, have sex and that, in a traditional context being misinterpreted.' The sense of alienation this provoked in Fay led her to feel 'foreign the whole time, and very, very cut off from the [Timorese] culture.'

Confronting responses to Western women were also held to be influenced by notorious patterns of predatory Western sex tourism in developing countries. Thus, Elly believed the approaches by Timorese men were shaped by expectations that 'wealthy, single women go to Indonesia [to] pick up a toy-boy,' or by hopes that a wealthy Western woman might be able to give 'a golden handshake out of some situation.' As Dana explained: 'Well if you're a Westerner you've got wealth, and if you're a woman thenand if you're a Western woman then that means you're promiscuous or, you know, possibly promiscuous. So, you're a bit of a target and a bit of an intrigue I guess, that's how it felt to me.'

In these complex, unresolved patterns of engagement, bringing together threat and desire, the women sensed that they were not only the target of resentment and 'hatred,' but also of what Fay had described as 'an underlying antagonism about Western sexuality' for which women were to blame.

\section{Monitoring the self}

The awareness of being watched and confronted was discomforting, and brought about 
changes in the women's spatial mobility and feelings about themselves. On the streets and on the beaches, an increased sensitivity to being identified as Western, and potentially associated with a code of behaviour that could be perceived by nonWesterners as immoral, began to shift teachers' images of what was appropriate in this context. As Fay observed: 'You end up feeling that you're blaming yourself for not being a good Catholic girl and all that, there's all sorts of things about behaving appropriately in someone else's culture, but how much you actually can change yourself- we're probably all inappropriate in the culture to come extent.'

In response to their sense of cultural inappropriateness, the women adopted strategies of rigorous self-monitoring and regulation in order to negotiate an acceptable appearance in public space. These strategies involved practices of taming the unacceptable female body by restricting mobility and exposure.

\section{Spatial confinement}

For some, the simplest way to avoid harassment was to remain cocooned in the private domain, the space traditionally allocated to women. While the public sphere, and by extension imperial space, has been the domain of white Western masculinity, the private domain has been associated with feminine, domestic pursuits. In this division, the exclusion of women from the public, political domain has been justified by the representation of females as natural, maternal creatures 'beyond culture and society, compelled to remain in the private domestic sphere' (Rose 1993: 32). Respecting, and in effect reproducing this traditional division, some women aid workers chose to limit their own mobility, and suffered a sense of isolation as a consequence. Thus, Elly recalled that the advice and warnings about the threat of danger in public spaces hindered her physical freedom: 'Yeah it did restrict my movement, but I was pretty careful anyway, at night time, well we all were I guess. Just because of the general climate of people saying be careful, and you'd feel a bit nervous.' For Helen, the result was a sense of spatial confinement, and she lamented: 'I feel a bit marooned in the expatriate enclave and I miss [my] freedom of movement.'

When they did venture out, the women tended to heed official warnings. They rarely went walking alone and, even when in pairs, restricted the places in which they were seen. Certain routes were preferable in order to avoid harassment, and in Elly's account the public space of the streets was distinguished from the public space of the beach, 
indicating the geographic contingency of the regulatory regime:

There seemed to be a bit of a difference between which way you went, if you went right or left, from our houses. We went left [to the beach] once, and we got harassed, and then we went right after that [along the streets], and we hardly ever went left even though it's much nicer down the other way cause that's where the water was and everything, nice places for swimming and stuff, but so, we kind of just went the other way which is a lot more public.

\section{Bodily confinement}

As well as curtailing their own mobility, the teachers also regulated their own bodily performance and appearance in an effort to become appropriate, and to bridge the gap between different cultural discourses around embodiment. For many, this entailed an attempt to be spatially inconspicuous, and therefore acceptable, by adopting modest attire, or choosing to swim in full clothing.

Claiming a particular expertise in cultural sensitivity by virtue of having 'been in Asia for a bit,' Kate adopted a modest form of beach attire: 'these long legged things' and 'a sun-block top to put on top of the bathing suit.' Her own strategies of cultural adaptation, involving a veiling of the body, were contrasted with the behaviour of younger Western women, who she condemned as culturally insensitive and therefore to be blamed for provoking a negative reaction amongst the Timorese:

I think some of the young Americans and Australians are begging for trouble with what they wear to swimming and stuff like that, and you know, they just think what's appropriate for us here [in Australia] is appropriate for us there [in Timor], whereas (...) But yeah, just things like that, it's an insensitivity (...) and even some of the UN workers who were highly respected and appreciated for what they do, they're just breaking cultural things left, right and centre.

In a move of reflexivity, Kate nevertheless acknowledged that her own performances might yet be unwittingly inappropriate, thus reinforcing her commitment to cultural sensitivity: 'And then I shouldn't say anything because, unknowingly I could have been doing some things as well.'

On dry land, a similar form of bodily veiling as a mode of cultural accommodation was adopted by Fay, on the advice of her students acting as cultural mediators: 'The veneer is there, you know the students would actually say, "you must wear sleeves," they knew what was socially acceptable and what wasn't. I did wear the blue sack [a large, shapeless blue dress]. That was my concession to Timor.' Fay's concession implied an acknowledgement that her dress served as a veneer, a mask, a means of passing unnoticed in a public domain regulated by a different set of gendered cultural norms. 


\section{Presenting a-sexual readings of the body}

In addition to deploying these adaptive strategies, in some cases women were able to refuse sexualised readings of their body by calling on various alternative positionings that relied on elder status or professional status. Some of the older women, for example, expressed a greater sense of freedom or confidence in their use of public space. For example, Kate claimed that she 'never felt threatened at all' because she suspected that 'the grey hair earns a lot of respect.' Similarly unfazed by the hassling that upset other women teachers, Carol explained that when followed and approached by Timorese men during her walks on the beach, she had simply to announce, in a prim and proper fashion, that she was an 'English teacher,' and 'to say in Indonesian, quite firmly, to go away.' Her professional identity was called upon as a discursive form of protective veil against unwanted sexual attention.

This reading of the professional body of the teacher seemed to prevail as the women entered the institutional space of the campus. Regardless of the harassment in the streets and on the beaches, it never occurred in the grounds of the university, where the women appeared to be read not as sexed bodies, but in terms of a professional identity produced in a specific place. Elly demonstrated this spatial contrast succinctly: 'You couldn't lie on the beach, you did get completely harassed there. And certainly I got followed around in town a fair bit too. But not on campus: I was "the teacher" on campus.' The particular space in which she appeared interacted with how she felt she was perceived and produced as a subject: the teaching space of the campus created a different meaning for her body.

\section{Conclusion}

In the accounts of white women development workers in transitional East Timor, a stark difference is apparent in their responses to approaches made by men from the foreign community and men from the Timorese community. Whereas the women took up oppositional positions in relation to perceptions of hegemonic masculinity in the international community, their positioning in relation to Timorese men was more complex and ambiguous, as discourses of gender equality and sexual freedom came into conflict with discourses of tolerance towards perceived cultural difference. This contrasting positioning echoed the ambiguous position of white women in the colonial projects of an earlier era. 
From the women's perspective, a sense of unresolved disquiet remained in relation to the gendered spatiality of the contact zone. Just as public space has historically been constructed in the West as a masculine sphere so, too, can contemporary development contexts be read as intercultural public spaces that reproduce normative gender hierarchies. From the perspective of women teachers, transitional East Timor was experienced as a domain for masculine intervention and agency, where foreign men were positioned at the head of public institutions charged with the regulation and control of the development context as a public space. Development projects, international organisations, diplomatic missions and the military served to sustain patriarchal regimes akin to those of the imperial explorers, mapping and surveying the landscape, producing plans and defending the territory against external threats. In this space, sexual and racial desire became sites for the transfer of power: women experienced the marginalising effects of being cast as an anomaly, found their mobility curtailed, and felt themselves subject, through the male gaze, to surveillance, monitoring and control. Returning the gaze, women saw the patriarchal and sexist regimes of Western men as doubly inappropriate, on the one hand exemplifying the archaic double standards of a different era, and on the other hand, transgressing perceived gender boundaries of the local context.

In the intercultural contact zone of development, gender as a dimension of teachers' subjectivity was entwined with various axes of embodied difference, particularly those implicated in the colonial legacies attached to whiteness and economic advantage. In this location, the intersection of whiteness and the female body in the public domain appeared to be read in a negative way by Timorese men, giving rise to suspicion and harassment. And yet the teachers in this study responded to such harassment by asserting discourses of cultural sensitivity, even at the expense of a commitment to personal freedom and gender equality. In public spaces, women regulated their own mobility, disguised their bodies by veiling them in modest, missionary clothes to obscure femaleness, and at times invoked protection through more powerful social and professional identities. These disguises suggest an attempt to androgynise or discipline the space of the unacceptable female body in order to enable women to appear, under the gaze of both local and foreign eyes, as appropriate and legitimate participants in the public domain. Women's awareness of complicity in the foreign occupation of East Timor was thus translated into a self-positioning as intruder into another sovereign 
cultural domain, and claims of gender equality receded in the face of discourses of tolerance for cultural difference.

The accounts of white women in the development milieu of transitional East Timor demonstrate that gendered participation, under circumstances of occupation and intervention, remains a troublesome experience. These gendered, geopolitical relations in the teachers' narratives demonstrate the weight of meaning attached to personal and interpersonal space, and highlight the complexity of development that defies reduction to a singular narrative of social and economic progress. Overall, despite a development rhetoric of progress towards supposedly universal goals of social justice and gender equality, in conditions of intervention and occupation gender remains a problematic dimension of subjectivity where complex geometries of power intersect with patriarchal and sexist regimes, and women's roles continue to be defined in relation to masculine desire.

\section{Acknowledgements}

The research was supported by funding from the ELSSA Centre, University of Technology, Sydney.

\section{Reference List}

Appleby, R. 2010, ELT, Gender and International Development: Myths of Progress in a Neocolonial World, Multilingual Matters, Bristol.

Appleby, R. 2009, 'Unruly Others: Language Teachers and the Policing of Gender in International Development,' Journal and Proceedings of Gender Awareness in Language Education, [Online], vol. 2, no. 1, pp. 4-14. Available: http://www.gale-sig.org/website/the gale journal.html [Accessed 7 February 2010]

Charlesworth, H. 2008, 'Are Women Peaceful? Reflections on the Role of Women in Peace-building,' Feminist Legal Studies, vol. 16, 347-361.

Charlesworth, H. \& Wood, M. 2002, 'Women and Human Rights in the Rebuilding of East Timor,' Nordic Journal of International Law, vol. 71, 325-348.

Chopra, J. 2000, 'The UN's Kingdom of East Timor,' Survival, vol. 42, no. 3, 27-39.

Chopra, J. 2002, 'Building State Failure in East Timor,' Development and Change, vol. 33, no. 5, 9791000 .

De Araujo, M. 2007, 'Oxfam and Partners in East Timor: Creating a Voice for Women and Carving a Space of that Voice,' in Challenges and Possibilities: International Organisations and Women in Timor-Leste, (eds) D. Grenfell \& A. Trembath, Globalism Institute, RMIT University, Melbourne, Australia, 19-25.

Duffield, M. 2002, 'Social Reconstruction and the Radicalization of Development: Aid as a Relation of Global Liberal Governance,' Development and Change, vol. 33, no. 5, 1049-1071.

Eisenstein, A. 2007, Sexual Decoys: Gender, Race and War in Imperial Democracy. Zed Books, London.

Hawthorne, S. 2004, 'The Political Uses of Obscurantism: Gender Mainstreaming and Intersectionality,' Development Bulletin, The Australian Development Studies Network, ANU, vol. 64, 87-91. 
Hunt, J. 2004, 'Gender and Development,' in Key Issues in Development, (eds) D. Kingsbury, J. Remenyi J. Mckay \& J. Hunt, Palgrave Macmillan, Basingstoke \& New York, 243-265.

Joshi, V., 2007, 'Creating and Limiting Opportunities: Women's Organizing and the UN in East Timor,' in Challenges and Possibilities: International Organisations and Women in Timor-Leste, (eds) D. Grenfell \& A. Trembath, Globalism Institute, RMIT University, Melbourne, Australia, 13-16.

Mazurana, D., Raven-Roberts, A., Parpart, J. \& Lautze, J. 2005, Gender, Conflict, and Peacekeeping. Rowman \& Littlefield, Lanham.

Mills, S. 1994, 'Knowledge, Gender, and Empire,' in Writing Women and Space: Colonial and Postcolonial Geographies, (eds) A. Blunt \& G. Rose, Guilford Press, New York, 20-50.

O'Kane, M. 2001, 'Revolution Turns against its Own,' The Guardian Weekly, 1-7 February, 21.

Pearson, R., \& Jackson, C. 1998, 'Interrogating Development: Feminism, Gender and Policy,' in Feminist

Visions of Development, (eds) C. Jackson \& R. Pearson, Routledge, London and New York, 1-16.

Pratt, M. L. 1992, Imperial Eyes: Travel Writing and Transculturation. Routledge, London.

Rose, G. 1993, Feminism and Geography: The Limits of Geographical Knowledge. Polity Press, Cambridge.

Spivak, G. 1994, 'Can the Subaltern Speak? Speculations on Widow Sacrifice,' in Colonial Discourse and Post-Colonial Theory: A Reader, (eds) P. Williams \& L. Chrisman, Harvester Wheatsheaf, New York and London, 66-111.

Stoler, A. L. 1995, Race and the Education of Desire: Foucault's History of Sexuality and the Colonial Order of Things. Duke University Press, Durham.

Sword Gusmao, K. 2003, A Woman of Independence. Pan Macmillan, Sydney.

Wells, J., \& McEwan, T. (2004). 'Gender Mainstreaming: Moving from Principles to Implementation,' Development Bulletin, The Australian Development Studies Network, ANU, no. 64, 31-33.

Yeoh, B. S. A., Teo, P., \& Huang, S. 2002, 'Women's Agencies and Activisms in the Asia-Pacific Region,' in Gender Politics in the Asia-Pacific Region, (eds) B. S. A. Yeoh, P. Teo \& S. Huang, Routledge, London \& New York, 1-16. 